\title{
Front Matter: Volume 8248
}

, "Front Matter: Volume 8248," Proc. SPIE 8248, Micromachining and Microfabrication Process Technology XVII, 824801 (17 March 2012); doi: 10.1117/12.928102

SPIE. Event: SPIE MOEMS-MEMS, 2012, San Francisco, California, United States 


\section{PROCEEDINGS OF SPIE}

\section{Micromachining and Microfabrication Process Technology XVII}

Mary Ann Maher

Paul J. Resnick

Editors

24 and 26 January 2012

San Francisco, California, United States

Sponsored by

SPIE

Cosponsored by

Dyoptyka (Ireland)

VUZIX Corporation (United States)

Published by

SPIE 
The papers included in this volume were part of the technical conference cited on the cover and title page. Papers were selected and subject to review by the editors and conference program committee. Some conference presentations may not be available for publication. The papers published in these proceedings reflect the work and thoughts of the authors and are published herein as submitted. The publisher is not responsible for the validity of the information or for any outcomes resulting from reliance thereon.

Please use the following format to cite material from this book:

Author(s), "Title of Paper," in Micromachining and Microfabrication Process Technology XVII, edited by Mary Ann Maher, Paul J. Resnick, Proceedings of SPIE Vol. 8248 (SPIE, Bellingham, WA, 2012) Article CID Number.

ISSN 0277-786X

ISBN 9780819488916

Published by

SPIE

P.O. Box 10, Bellingham, Washington 98227-0010 USA

Telephone +1 3606763290 (Pacific Time) · Fax +1 3606471445

SPIE.org

Copyright (C) 2012, Society of Photo-Optical Instrumentation Engineers

Copying of material in this book for internal or personal use, or for the internal or personal use of specific clients, beyond the fair use provisions granted by the U.S. Copyright Law is authorized by SPIE subject to payment of copying fees. The Transactional Reporting Service base fee for this volume is $\$ 18.00$ per article (or portion thereof), which should be paid directly to the Copyright Clearance Center (CCC), 222 Rosewood Drive, Danvers, MA 01923. Payment may also be made electronically through CCC Online at copyright.com. Other copying for republication, resale, advertising or promotion, or any form of systematic or multiple reproduction of any material in this book is prohibited except with permission in writing from the publisher. The CCC fee code is 0277-786X/12/\$18.00.

Printed in the United States of America.

Publication of record for individual papers is online in the SPIE Digital Library.

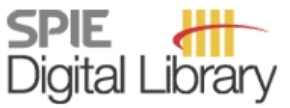

SPIEDigitalLibrary.org

Paper Numbering: Proceedings of SPIE follow an e-First publication model, with papers published first online and then in print and on CD-ROM. Papers are published as they are submitted and meet publication criteria. A unique, consistent, permanent citation identifier (CID) number is assigned to each article at the time of the first publication. Utilization of CIDs allows articles to be fully citable as soon as they are published online, and connects the same identifier to all online, print, and electronic versions of the publication. SPIE uses a six-digit CID article numbering system in which:

- The first four digits correspond to the SPIE volume number.

- The last two digits indicate publication order within the volume using a Base 36 numbering system employing both numerals and letters. These two-number sets start with $00,01,02,03,04$, $05,06,07,08,09,0 A, 0 B \ldots 0 Z$, followed by 10-1Z, 20-2Z, etc.

The CID number appears on each page of the manuscript. The complete citation is used on the first page, and an abbreviated version on subsequent pages. Numbers in the index correspond to the last two digits of the six-digit CID number. 


\section{Contents}

$\checkmark$ Conference Committee

vii New optical, acoustic, and electrical diagnostics for the developing world (Plenary Paper) [8251-103]

S. L. Neale, C. Witte, Y. Bourquin, C. Kremer, A. Menachery, Y. Zhang, R. Wilson, J. Reboud,

J. M. Cooper, Univ. of Glasgow (United Kingdom)

\section{PLENARY SESSION}

824802 Powering the wireless world with MEMS (Plenary Paper) [8248-102]

S. B. Schaevitz, Lilliputian Systems, Inc. (United States)

\section{SESSION 1 DEVICES AND APPLICATIONS}

824803 Optically transparent, flexible pressure sensor array micromachined utilizing plasma assisted bonding [8248-01]

J. Yan, Univ. of California, Davis (United States)

824804 Rotary MEMS comb-drive actuator with large deflection for photonic applications [8248-02] M. Q. Huda, T. M. F. Amin, Univ. of Alberta (Canada); Y. Ning, G. McKinnon, Norcada Inc. (Canada); J. Tulip, Boreal Laser, Inc. (Canada); W. Jäger, Univ. of Alberta (Canada)

824805 Photovoltaic retinal prosthesis for restoring sight to the blind: implant design and fabrication [8248-03]

L. Wang, Stanford Univ. (United States); K. Mathieson, Stanford Univ. (United States) and Univ. of California, Santa Cruz (United States); T. I. Kamins, J. Loudin, L. Galambos, J. S. Harris,

D. Palanker, Stanford Univ. (United States)

824806 Micromachined edge illuminated optically transparent automotive light guide panels [8248-04]

R. A. Ronny, G. K. Knopf, The Univ. of Western Ontario (Canada); E. Bordatchev, M. Tauhiduzzaman, S. Nikumb, National Research Council Canada (Canada)

\section{SESSION 2 MICROSTRUCTURE ENGINEERING}

$824807 \quad$ Fabrication of microstructures with continuous surface profiles and very large sag heights by laser lithography [8248-06]

J. Dunkel, Fraunhofer Institute for Applied Optics and Precision Engineering (Germany) and Friedrich-Schiller-Univ. Jena (Germany); F. Wippermann, A. Bräuer, Fraunhofer Institute for Applied Optics and Precision Engineering (Germany)

824808 Design of experiment for the optimisation of deep reactive ion etching of silicon inserts for microfabrication [8248-07]

K. Wallis, C. P. Shaw, J. R. Alcock, Cranfield Univ. (United Kingdom) 
824809 Impact of initial surface parameters on the final quality of laser micro-polished surfaces [8248-08]

M. Chow, The Univ. of Western Ontario (Canada); E. V. Bordatchev, National Research

Council Canada (Canada); G. K. Knopf, The Univ. of Western Ontario (Canada)

\section{SESSION $3 \quad$ LASER PROCESSING}

$82480 \mathrm{C}$ High aspect ratio microfeatures with laser texturing in mixed ablative-melting regime [8248-11]

P. M. Romero, N. Otero, A. González, P. Vázquez, Asociación de Investigación Metalúrgica del Noroeste (Spain)

$8248 \mathrm{OF} \quad$ Fabrication qualities of micro-gratings encoding dependence on laser parameters by two-beam femtosecond lasers interference [8248-14]

X. Wang, F. Chen, H. Liu, H. Bian, Q. Yang, J. Si, X. Hou, Xi'an Jiaotong Univ. (China)

\section{SESSION 4 MEMS FABRICATION}

$82480 G$ Bosch-like method for creating high aspect ratio poly(methyl methacrylate) (PMMA) structures [8248-15]

M. Haiducu, Simon Fraser Univ. (Canada); D. Sameoto, Univ. of Alberta (Canada); I. Foulds, King Abdullah Univ. of Science and Technology (Saudi Arabia); R. W. Johnstone, Teledyne DALSA Semiconductor (Canada); A. M. Parameswaran, Simon Fraser Univ. (Canada)

$8248 \mathrm{OH} \quad$ Stress engineering for free-standing SU-8 2002 thin film devices [8248-16] K. W. Oliver, S. J. Lukes, M. J. Moghimi, D. L. Dickensheets, Montana State Univ. (United States)

8248 ol Numerical simulation of hot imprint process of periodical lamellar microstructure into polycarbonate [8248-17]

R. Gaidys, B. Narijauskaitè, A. Palevičius, G. Janušas, Kaunas Univ. of Technology (Lithuania)

\section{POSTER SESSION}

$82480 \mathrm{~J}$ Electro-hydrodynamic printing using hole-type electrode [8248-18]

S. Lee, H. Kim, J. Chung, Korea Univ. (Korea, Republic of)

8248 OK Laser-based microstructuring of materials surfaces using low-cost microlens arrays [8248-19]

D. Nieto, CIDETEC (Spain), National Univ. of Ireland, Galway (Ireland), and Univ. de Santiago de Compostela (Spain); G. Vara, J. A. Diez, CIDETEC (Spain); G. M. O'Connor, National Univ. of Ireland, Galway (Ireland); J. Arines, C. Gómez-Reino, M. Flores-Arias, Univ. de Santiago de Compostela (Spain)

Author Index 


\section{Conference Committee}

Symposium Chair

Harald Schenk, Fraunhofer Institute for Photonic Microsystems

(Germany)

Symposium Cochair

David L. Dickensheets, Montana State University (United States)

Conference Chairs

Mary Ann Maher, SoftMEMS (United States)

Paul J. Resnick, Sandia National Laboratories (United States)

Program Committee

Mu Chiao, The University of British Columbia (Canada)

Sanjay Krishna, The University of New Mexico (United States)

Tamal Mukherjee, Carnegie Mellon University (United States)

Metin Ozen, Ozen Engineering, Inc. (United States)

Yu-Chuan Su, National Tsing Hua University (Taiwan)

T. C. Yih, Oakland University (United States) 
Downloaded From: https://www.spiedigitallibrary.org/conference-proceedings-of-spie on 26 Apr 2023

Terms of Use: https://www.spiedigitallibrary.org/terms-of-use 